\title{
2012s-11
}

\section{Is East Asia's Economic Fate Chained to the West?}

\author{
Alyson Ma, Ari Van Assche
}

\begin{tabular}{c}
\hline Série Scientifique \\
Scientific Series
\end{tabular}

\author{
Montréal \\ Mai 2012
}

(C) 2012 Alyson Ma, Ari Van Assche. Tous droits réservés. All rights reserved. Reproduction partielle permise avec citation du document source, incluant la notice $($ C.

Short sections may be quoted without explicit permission, if full credit, including (C) notice, is given to the source.
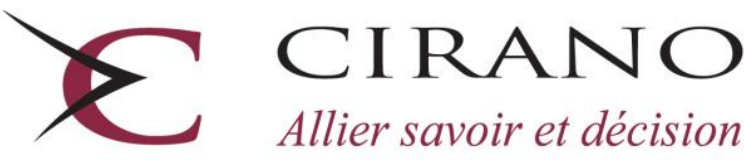

Allier savoir et décision

Centre interuniversitaire de recherche en analyse des organisations 


\section{CIRANO}

Le CIRANO est un organisme sans but lucratif constitué en vertu de la Loi des compagnies du Québec. Le financement de son infrastructure et de ses activités de recherche provient des cotisations de ses organisations-membres, d'une subvention d'infrastructure du Ministère du Développement économique et régional et de la Recherche, de même que des subventions et mandats obtenus par ses équipes de recherche.

CIRANO is a private non-profit organization incorporated under the Québec Companies Act. Its infrastructure and research activities are funded through fees paid by member organizations, an infrastructure grant from the Ministère du Développement économique et régional et de la Recherche, and grants and research mandates obtained by its research teams.

\section{Les partenaires du CIRANO}

\section{Partenaire majeur}

Ministère du Développement économique, de l'Innovation et de l'Exportation

\section{Partenaires corporatifs}

Autorité des marchés financiers

Banque de développement du Canada

Banque du Canada

Banque Laurentienne du Canada

Banque Nationale du Canada

Banque Royale du Canada

Banque Scotia

Bell Canada

BMO Groupe financier

Caisse de dépôt et placement du Québec

\section{CSST}

Fédération des caisses Desjardins du Québec

Financière Sun Life, Québec

Gaz Métro

Hydro-Québec

Industrie Canada

Investissements PSP

Ministère des Finances du Québec

Power Corporation du Canada

Rio Tinto Alcan

State Street Global Advisors

Transat A.T.

Ville de Montréal

\section{Partenaires universitaires}

École Polytechnique de Montréal

HEC Montréal

McGill University

Université Concordia

Université de Montréal

Université de Sherbrooke

Université du Québec

Université du Québec à Montréal

Université Laval

Le CIRANO collabore avec de nombreux centres et chaires de recherche universitaires dont on peut consulter la liste sur son site web.

Les cahiers de la série scientifique (CS) visent à rendre accessibles des résultats de recherche effectuée au CIRANO afin de susciter échanges et commentaires. Ces cahiers sont écrits dans le style des publications scientifiques. Les idées et les opinions émises sont sous l'unique responsabilité des auteurs et ne représentent pas nécessairement les positions du CIRANO ou de ses partenaires.

This paper presents research carried out at CIRANO and aims at encouraging discussion and comment. The observations and viewpoints expressed are the sole responsibility of the authors. They do not necessarily represent positions of CIRANO or its partners. 


\title{
Is East Asia's Economic Fate Chained to the West?*
}

\author{
Alyson $\mathrm{Ma}^{\dagger}$, Ari Van Assche
}

\section{Résumé / Abstract}

In the past few decades, East Asia has become a key player in the global value chains of products that are consumed in Western markets. In this paper, we discuss how idiosyncratic shocks propagate through global value chains, and assess how this has affected East Asian countries' vulnerability to demand shocks in the West.

Mots clés/Keywords: global value chains, international trade, East Asia, international transmission of business cycles.

\footnotetext{
* This paper acted as a background paper for the Asian Development Bank's 2012 Asian Development Outlook. We gratefully acknowledge funding from the Asian Development Bank to conduct the research.

${ }^{\dagger}$ University of San Diego.

¥HEC Montréal and CIRANO, ari.van-assche@ hec.ca .
} 


\section{Introduction}

In the past few decades, East Asia has become a key player in the global value chains (GVCs) of products that are consumed in Western markets. Many income-sensitive, hightechnology products that can be found on the shelves of Best Buy in the United States or FNAC in France incorporate components produced in Japan, the Asian Dragons (Hong Kong, Rep. of Korea, Singapore and Taiwan), in the five largest ASEAN countries (Indonesia, Malaysia, Philippines, Thailand and Vietnam) and in China.

Among academics and policymakers, this trend has led to growing concern that the region is becoming more vulnerable or "coupled" to business cycle movements in the West. Economic downturns in the West, so it is argued, can reverberate globally through supply chains, leading to significant export reductions and economic contractions in East Asia. This concern has been fueled by the results of a number of recent empirical studies. Using the Asian International Input-Output table, Pula and Peltonen (2011a) estimate that East Asia's dependence on export markets has steadily risen since 1995. Similarly, Athukorala and Kohpaiboon (2011) analyze East Asia's changing trade patterns and conclude that the region's trade dependence of the rest of the world has increased in the past few decades. This rising trade dependence is found to have increased the region's macroeconomic dependence on the West. Park et al. (2011) estimate that the real economic interdependence between East Asia and the West has significantly increased since the 1997/98 Asian Financial Crisis. ${ }^{1}$

In this paper, we aim to analyze the role of GVCs in the transmission of business cycle shocks. For this purpose, we have organized the paper into 6 sections. In section 2, we document East Asia's growing role in the GVCs. In section 3, we discuss the various types of idiosyncratic shocks that can propagate through GVCs. In section 4, we then illustrate how traditional measures of countries' exposure to external demand shocks inadequately capture the transmission channels of these idiosyncratic shocks. In section 5, we discuss the role of GVCs in the trade collapse during the Global Recession of 20082009. Finally, we in section 6 provide concluding remarks.

\section{East Asia's Role in GVCs ${ }^{2}$}

The organization of international production has fundamentally changed in the past few decades. Thanks to reductions in communication costs, transportation costs and other

\footnotetext{
${ }^{1}$ Dees and Vansteenkiste (2007), in contrast, argue that the East Asian economic region is largely decoupled from the West.

${ }^{2}$ Our data sources and definitions are presented in Appendix A.
} 
trade barriers, many firms have sliced up their supply chains, and have dispersed their production activities across multiple countries. At the same time, they have outsourced large portions of their supply chain activities to external firms. As a result, the production

process of consumer goods now involves many firms that are located in various countries across the globe, giving rise to GVCs.

An implication of the rise of GVCs is that international trade is increasingly dominated by trade in tasks (within GVCs) instead of trade in goods (Grossman and Rossi-Hansberg 2008). Currently, trade in intermediate inputs accounts for roughly two-thirds of international trade (Johnson and Noguera 2012). In addition, countries rely more and more on imported inputs to produce their exports. For instance, Hummels et al. (2001) use input-output tables for 14 countries and estimate that the import content on average accounted for nearly $21 \%$ of the exports value in 1990 . Using more recent data, Miroudot and Ragoussis (2009) estimate that the average import content of exports has risen from $26 \%$ in 1995 to $31 \%$ in 2005.

GVCs have expanded asymmetrically across industries, predominantly emerging in durable goods sectors such as electronics and automobiles (Bems et al. 2011, Miroudot and Rigoussis 2009). As is shown in figure 1, the import content embodied in exports is on average larger for durable goods than for non-durables goods and services. For key durable goods sectors such as Radio, TV, communications equipment, Office machinery and computers and Automobiles, import content represented more than $40 \%$ of exports value in 2005 . For services, import content amounts to less than $15 \%$.

\section{[Figure 1 about here]}

East Asian economies have taken on a key role in the GVCs of durable goods, effectively turning the region into the "factory of the world". Trade patterns reflect East Asia's growing dominance in durable goods sectors. From 2000 to 2007, East Asia's share in world durable goods exports has grown from $35 \%$ to $42 \%$. The growth in the share of the world's durable goods exports is not only due to its overall trade expansion, but also due to its specialization in durable goods trade. As shown in figure 2, the exports of East Asian economies are more heavily concentrated in durable goods than the rest of the world. With the exception of Indonesia and Vietnam, the share of durable goods exports in total exports exceeded $45 \%$ for all East Asian countries in 2007. This is largely due to 
East Asia's key role in the GVCs of electronics. Electronics constituted more than half of durable goods exports in 2007 for the region, except for Vietnam, Indonesia and Japan. ${ }^{3}$

\section{[Figure 2 about here]}

While durable goods trade has clustered in East Asia, the final consumption of durable goods has remained concentrated in North America and Europe. We can see this by dissecting East Asia's durable goods trade into intermediate and final goods trade. Figure 3 demonstrates that East Asian countries heavily trade intermediate goods among each other to produce durable final goods. Indeed, 61\% of East Asia's intermediate durables were imported intra-regionally in 2007. In contrast, 55\% of East Asia's exports of final durable goods were destined to non-Asian OECD countries in 2007.

\section{[Figure 3 about here]}

Within East Asia, economies play different roles in GVCs depending on their level of economic development. As is shown in figure 4, the most developed East Asian economy, Japan, specializes in the upstream production of sophisticated intermediate goods such as semiconductors. This is reflected in its trade patterns. In 2007, Japan disproportionately imported intermediate durables when compared to the rest of the world (see appendix B). The high-income Asian dragons (Hong Kong, Rep. of Korea, Singapore and Taiwan) and Malaysia (but also the Philippines), in turn, are located in the middle of the chain where they specialize in the processing of intermediate goods. While they disproportionately import intermediate durables, intermediate goods also make up a larger-than-average share of their durable goods exports. The middle-income countries China and Thailand specialize in the downstream assembly of final durable goods. ${ }^{4}$ They disproportionately import intermediate durables, and specialize in the export of final durable goods. Finally, the high-income Western economies U.S. and E.U. serve as dominant markets for final goods, intensively importing final goods from abroad.

\section{[Figure 4 about here]}

Plotting the countries according to their position in GVCs (x-axis) and their level of development (y-axis) gives rise to the well-known smiley shape that has been identified for the value chains of electronics products (Mudambi 2008). Upstream stages such as

\footnotetext{
${ }^{3}$ Gangnes and Van Assche $(2010,2012)$ provide a detailed discussion of East Asia's role in electronics value chains.

${ }^{4}$ In Appendix B, we explain the methodology used to determine countries' positions in GVCs.
} 
design, $\mathrm{R} \& \mathrm{D}$ and production of sophisticated components are generally located in developed countries, while manufacturing and especially final assembly activities are relocated to developing countries. Finally, the downstream activities marketing and consumption once again take place in developed countries. ${ }^{5}$

\section{GVCs and the International Propagation of Shocks}

East Asia's growing integration into GVCs has increased the entire region's exposure to country-specific shocks. A well-known empirical regularity in macroeconomics is the "trade-comovement puzzle." This states that country pairs that trade more with each other experience higher business cycle correlation (Frankel and Rose 1998). Recent empirical studies find that GVC linkages are a key driver of the trade-comovement puzzle (Burstein et al. 2005, Ng 2010), and especially in North-South trade (di Giovanni and Levchenko 2010). Three types of idiosyncratic shocks can be transmitted through GVC linkages: supply shocks, demand shocks, and credit shocks. We consider them in turn.

Consider the following example to explain the propagation of supply shocks along GVCs. Suppose that in figure 4 there is a sudden negative shock in the supply of Japanese components that reduces Japan's exports to the Asian dragons. If these components are not highly substitutable, the Asian dragons will not be able to process their components, therefore requiring them to reduce their exports to the final assembly platforms China and Thailand. The final assembly platforms, on their turn, will not be able to assemble as many final goods, thereby reducing their final goods exports to the consumer markets in the U.S. and E.U. The just-in-time nature of many GVCs implies that the speed of transmission across the chain can be almost instantaneous (de Backer 2011). As a result, the negative supply shock can lead to a synchronized trade decline for all GVC participants. This is precisely what happened in the aftermath of the 2011 Tohohoku earthquake and tsunami (Escaith et al. 2011). As soon as the disaster hit, the production of Japanese intermediate components dried up, creating a disruption of international supply chains in the automotive and electronics industry, and affecting the price and availability of these goods around the world.

GVCs can also transmit demand shocks across value chain participants. To see this, consider once again figure 4. Suppose there is a sudden decline in U.S. or E.U. demand for final durable goods. This would decrease the demand for imports from the final assembly platforms China and Thailand. In turn, since these final assembly platforms

\footnotetext{
${ }^{5}$ In line with the smile of value creation, Antràs et al. (2012) find that countries with stronger institutions and relative skill abundance specialize in downstream industries.
} 
heavily rely on imported components, they would react to the negative demand shock by importing fewer components from the Asian dragons. Moreover, the Asian dragons would react to the shock by importing fewer inputs from the next upstream stage, Japan. As a result, the negative demand shock can lead to a sudden, synchronized trade decline throughout the East Asian region.

A demand shock may even amplify as it moves up the GVC due to inventory adjustments (Alessandria et al. 2010, 2011, Altomonte et al. 2012). The logic for such a bullwhip effect is the following. Businesses typically face forecast errors in their sales against which they try to shelter by building safety stocks of inventories. When a downstream firm is confronted with a drop in demand for its final products, its first reaction is then to run down its inventories, therefore more than proportionally reducing its orders of upstream components (see figure 5). The upstream component processor, on its turn, reacts to the amplified drop in demand by also running down its inventories, leading to an even larger drop in the demand for imported components. As this inventory adjustment process propagates upstream, the demand shock continues to amplify.

\section{[Figure 5 about here]}

GVC linkages can aditionally transmit credit shocks along the chain. In international business, exporters routinely rely on external capital to cover substantial upfront costs that cannot be financed out of retained earnings or internal cash flows from operations. Indeed, a survey conducted by the World Bank finds that firms typically finance about $20 \%$ of their working capital with trade credit from banks or from their suppliers (Raddatz 2010). In addition to extensively using trade credit as a source of funds, most firms simultaneously grant credit to their customers (Fabbri and Klapper 2008). In GVCs where firms rely on each other for credit, a shock to the liquidity of one firm may cause a chain reaction in which other firms also get in financial difficulty (Kiyotaki and Moore 1997). Raddatz (2010) finds empirical support for the presence and relevance of credit shocks. Using data for 43 countries and 378 manufacturing industries pairs from 19802000, he estimates that an increase in the use of trade credit along the input-output chain linking two industries results in an increase in their output correlation.

Besides acting as a vehicle for transmitting idiosyncratic shocks internationally, trade within GVCs is also more sensitive to system-wide trade friction shocks than regular trade. To illustrate this, consider figure 6 . The left panel shows a traditional trade pattern where a product is entirely produced in country 2 and then exported to country 3 for consumption. The right panel shows a vertically specialized trade pattern within a GVC. 
Country 1 produces inputs and exports them to country 2. Country 2 uses the imported inputs to produce a final good. Finally, country 2 exports its output to country 3 for consumption. In the GVC, the input produced in country 1 ends up crossing borders two times, leading to a multiplication of trade frictions. Hummels et al. (2001) and Yi (2003) use this argument to explain how global tariff reductions can lead to a disproportionate growth in vertically specialized trade. But the converse is also true: a world-wide increase in trade frictions could lead to a magnified decrease in trade within GVCs. Using Chinese data, Gangnes et al. (2011) provide evidence that trade within GVCs is indeed more sensitive to global oil price shocks than regular trade.

\section{[Figure 6 about here]}

\section{GVCs and East Asia's Exposure to External Demand Shocks}

The rise of GVCs and their role in transmitting idiosyncratic shocks imply that traditional measures of a country's economic exposure to external demand shocks are biased. The standard way to measure a country's economic exposure through trade to an external demand shock is the amount of bilateral exports normalized by GDP. According to this measure, a country such as Malaysia whose exports of goods to the U.S. amounts to $19 \%$ of its GDP is considered more vulnerable to a U.S. recession than Taiwan for which exports to the U.S. are only $10 \%$ of its GDP.

The export-to-GDP ratio inaccurately measures a country's exposure to external demand shocks for two reasons. On the one hand, there is a downward bias (indirect exports bias) since the measure only considers a country's direct bilateral exports, while ignoring indirect exports through third countries. On the other hand, there is an upward bias (import content bias) since the measure ignores countries' reliance on imported inputs to produce its exports. In this section, we provide evidence of these two biases and investigate the true trade exposure of East Asian countries to Western demand shocks.

The export-to-GDP ratio may underestimate a country's exposure to external demand shocks since it only considers a country's direct bilateral exports, while ignoring indirect exports through third countries. This leads to an indirect exports bias. As we have seen above, a significant portion of East Asian countries' exports are first sent to other East Asian countries before being ultimately exported to the West for final consumption. These indirect exports are also vulnerable to demand shocks in the West, and may even become amplified upstream due to the bullwhip effect. We can illustrate the importance 
of the indirect exports bias with data from China's processing trade regime. ${ }^{6}$ Under this customs regime, firms located in China receive duty exemptions on imported inputs, but only if the processed goods are subsequently exported. As a result, all processing imports from East Asia by definition are indirectly exported to other countries. Figure 7 shows East Asia's importance as a supplier of inputs to China's processing trade regime. For all East Asian economies except Indonesia and Vietnam, more than $40 \%$ of their exports to China in 2007 were processing inputs. For Taiwan it amounted to almost $70 \%$ of their exports to China.

\section{[Figure 7 about here]}

More than 25\% of China's processing exports were destined for the U.S. and E.U. each. As a result, accounting for indirect exports significantly increases the East Asian countries' export-to-GDP ratios. Taiwan's export exposure to the U.S. increases by more than $7 \%$ when indirect exports are taken into account (see Figure 8). For most other East Asian countries the export exposure increases with 1-5\%. The results for East Asian countries' export exposure to the E.U. are similar.

\section{[Figure 8 about here]}

The bilateral export-to-GDP ratio may also overestimate a country's exposure to external demand shocks since it ignores countries' reliance on imported inputs to produce its exports. This leads to an import content bias. A country's exports value not only captures the value produced in the country (domestic value added) but also the value of the imported components embodied in the exports. When estimating a country's economic exposure to external demand shocks, one should only consider domestic value added. Any negative impact on the imported components is transmitted to the countries located upstream in GVCs. Johnson and Noguera (2012) provide an estimate for the size of import content bias. By combining input-output tables and bilateral trade data, they find that world-wide the domestic value added share of exports is only $73 \%$. In other words, $27 \%$ of world exports is the value of imported inputs embodied in these exports. Across East Asia, the domestic value added share varies widely, ranging from a low $37 \%$ for Singapore to a high $85 \%$ for Japan (see figure 9).

\section{[Figure 9 about here]}

\footnotetext{
${ }^{6}$ We only gauge the size of indirect exports through China here. East Asian countries may also indirectly export through other countries, increasing the indirect exports bias even more.
} 
To correct for the indirect export and import content biases, Johnson and Noguera (2012) estimate the value added content of bilateral trade. That is, they estimate the value added produced in a country $i$ that is ultimately consumed in country $j$. As is shown in figure 10, they find that a country's value added exports to the U.S. can differ significantly from its gross exports to the U.S, depending on their location in the GVC. ${ }^{7}$ Japan's value added exports to the U.S. exceed gross exports because (i) it relies little on imported inputs for its exports and (ii) it has large indirect exports to the U.S. by supplying intermediates to other East Asian countries. In contrast, for all other East Asian countries the value added exports to the U.S. is less than gross exports. China's value added exports to the U.S., for example, is only $60 \%$ of its gross exports because (i) it heavily relies on imported components for its exports and (ii) as a final assembly platform has relatively little indirect exports to the U.S.

\section{[Figure 10 about here]}

\section{GVCs and the Great Trade Collapse}

East Asia's trade collapse during the Global Recession of 2008-2009 illustrates how chained East Asia's trade has become to business cycles in the West. As we explain in this section, East Asia's trade collapse during the crisis was largely driven by a large negative demand shock for durable goods in the West that was rapidly transmitted and amplified through GVCs. System-wide increases in trade frictions associated with evaporating credit further intensified the collapse, but did not lead to a systematic propagation of credit shocks throughout GVCs.

The trade collapse in 2008-2009 differed from other episodes of trade declines after financial crises in three respects: its suddenness, severity, and synchronicity (Abiad et al. 2011, Baldwin 2009). In the first quarter of 2009, world trade dropped more than 30 percent compared to the first quarter of 2008. This trade collapse hit all countries simultaneously: with the lone exception of Egypt, all economies experienced a drop in trade during this period. East Asia was among the hardest hit regions. As is shown in figure 11, East Asian economies saw their trade drop between $20 \%$ and $40 \%$ in the first quarter of 2009 compared to the same period a year earlier.

\section{[Figure 11 about here]}

\footnotetext{
${ }^{7}$ Johnson and Noguera (2012) do not provide estimates for value added exports to the E.U.
} 
The disproportionate rise of GVCs in durable goods sectors helps explain the increased vulnerability of trade to business cycle shocks. Since components are cross-hauled (and double-counted) multiple times in GVCs, the rise of GVCs has raised the weight of durable goods in trade compared to its weight in GDP. Bems et al. (2010) indeed estimate that durable goods prior to the crisis had grown to almost $40 \%$ of trade, but amounted to only $10 \%$ of final demand (see figure 12). Given that consumers during a recession first and foremost hold off their purchases of durable goods, the transmission of demand shocks along GVCs of durable goods can induce trade to drop disproportionately compared to GDP.

\section{[Figure 12 about here]}

There is ample evidence that such an asymmetric demand shock (also called a composition effect) was the main culprit of the trade collapse during the Global Recession. Bems et al. (2010) estimate that between 2008 and 2009 the demand for durable goods fell by $32 \%$ in the U.S. and $23 \%$ in the E.U.-15, whereas demand for nondurables and services fell by less than $4 \%$. Using the global input-output table from Johnson and Noguera (2012), they find that the changing composition of final demand accounted for $70 \%$ of the decline in trade relative to GDP. Using a more elaborate structural model, Eaton et al. (2011) similarly find that asymmetric demand changes account for $80 \%$ of the global decline in the trade-to-GDP ratio during the crisis.

In line with the bullwhip effect, there is also evidence that demand shocks have been amplified upstream during the Global Recession. Using Chinese processing trade data, Ma and Van Assche (2011) find that processing imports across industries contracted more severely than processing exports in the first quarter of 2009 compared to a year earlier. As is shown in figure 13, with the exception of "motor vehicles", all durable goods sectors lie to the right of the 45 degree line, suggesting that processing imports dropped by a larger percent than processing exports. Similarly, Altomonte et al. (2012) used French firm-level data to show that trade in intermediates during the crisis overreacted to the final demand shock. Both results suggest that inventory adjustment along value chain may have contributed to the great trade collapse. This is confirmed by Alessandria et al. (2011), who find that two-thirds of the decline in U.S. automobile imports during the crisis can be attributed to firms running down their inventories rather than a fall in final sales of autos.

[Figure 13 about here] 
The system-wide rise of trade frictions associated with evaporating credit, increasing non-tariff barriers and home bias in government stimulus plans further intensified the trade collapse (Jacks et al. 2009, Eaton et al. 2011). For instance, the credit crunch at the height of the crisis resulted in a severe reduction in the availability of external finance. This hit international trade particularly hard since exporters are heavier users of trade finance than domestic firms (Ahn et al. 2011). ${ }^{8}$ Chor and Manova (2011) indeed find that during the crisis, countries with higher interbank rates and therefore tighter credit availability cut back their exports to the U.S. more. Using Belgian and French firm-level data, respectively, Behrens et al. (2011) and Bricongne et al. (2012) also find that credit constraints during the crisis significantly worsened the export positions of financially constrained firms. As we have discussed above, the system-wide rise of such trade frictions should disproportionately affect trade within GVCs. To our knowledge, however, no study has empirically verified this.

There is no evidence that the financial crisis propagated credit chain effects through GVCs. Had there been strong credit chain effects, one should observe that trade during the crisis fell significantly along the extensive margin, as firms systematically terminated trade relations due to liquidity problems. Behrens et al. (2011) and Bricongne et al. (2012) find no evidence of this for Belgian and French firms, with most of the trade adjustment occurring at the intensive margin.

\section{Concluding comments}

In this paper, we have demonstrated that East Asia's integration into GVCs has made the region more vulnerable to Western business cycle shocks than might be expected. We have also documented the importance of GVCs in triggering the East Asian trade collapse during the Global Recession of 2008-2009. Our analysis provides valuable lessons for the East Asian region's vulnerability to a deepening European debt crisis. Since the E.U. accounts for a substantial portion of global demand, a European recession can yet again send large demand shocks up the GVCs, leading to a sharp contraction in East Asia's trade. Such a trade collapse will be further intensified in the event that credit markets dry up and/or protectionism spikes.

\footnotetext{
${ }^{8}$ There are at least three reasons why exporters need more working-capital financing (Ahn et al. 2011). First, exporting entails important fixed costs such as the learning about export market profitability and about regulatory compliance. Second, exporting tends to take longer than domestic transactions because of the longer time lags associated with international trade. Third, exporting is a more risky activity than domestic activities alone.
} 
East Asia's export dependence on Western markets will likely start to decline in the postcrisis era. With incomes throughout the region rising faster than in the West, China's domestic market expanding rapidly, and the three free trade agreements of China, Japan and South Korea with the ASEAN entering into force, a rising share of the demand for East Asian output should shift intra-regionally in the decades to come. ${ }^{9}$ This rebalancing process, however, will likely be gradual and lengthy. As a result, the processes described in this paper through which demand shocks in the West will reverberate throughout the East Asian region through GVCs can be expected to continue for years to come.

\footnotetext{
${ }^{9}$ In a recent paper, Pula and Paltonen (2011b) find evidence that in 2009 the previous trend of growing export dependence has reversed and the share of value added originating from intra-regional demand has increased substantially. However, it is unclear if this is a true trend reversal or a temporary effect related to the crisis.
} 


\section{Bibliography}

Abiad A., P. Mishra, and Topalova P. 2011. "How Does Trade Evolve in the Aftermath of Financial Crises?” IMF Working Paper WP113.

Ahn, J., M. Amiti, and D. Weinstein. 2011. "Trade Finance and the Great Trade Collapse." American Economic Review Paper and Proceedings 101(3), 298-302.

Alessandria G., J. Kaboski, and V. Midrigan. 2010. "The Great Trade Collapse of 20082009: An Inventory Adjustment?” IMF Economic Review 58(2), 254-294.

Alessandria G., J. Kaboski, and V. Midrigan. 2011. "U.S. Trade and Inventory Dynamics." American Economic Review Papers and Proceedings 101(3), 303-307.

Altomonte, C., F. Di Mauro, G. Ottaviano, A. Rungi, and V. Vicard. 2012. "Global Value Chains during the Great Trade Collapse: A Bullwhip Effect?" ECB Working Paper Series No. 1412.

Antràs, P., D. Chor, T. Fally, and R. Hillberry. 2012. "Measuring the Upstreamness of Production and Trade Flows." American Economic Review Papers and Proceedings, forthcoming.

Athukorala, P., and A. Kohpaiboon. 2011. "East Asia in World Trade: The Decoupling Fallacy, Crisis and Policy Challenges." Australia National University Trade and Development Working Paper No. 2010/05.

Baldwin, R. (Ed.). 2009. The Great Trade Collapse: Causes, Consequences and Prospects.VoxEU Ebook.

Behrens, K., G. Corcos, and G. Mion. 2011. “Trade Crisis? What Trade Crisis?” CIRPÉE Working Paper No. 11-17.

Bems, R., S. Johnson, and K.-M. Yi. 2010. "Demand Spillovers and the Collapse of Trade in the Global Recession." IMF Economic Review 58(2), 295-326.

Bems, R., S. Johnson, and K.-M. Yi. 2011. "Vertical Linkages and the Collapse of Global Trade." American Economic Review Papers and Proceedings 101(3), 308-312.

Bricongne, J., L. Fontagné, G. Gaulier, D. Taglioni, and V. Vicard. 2012. "Firms and the Global Crisis: French Exports in the Turmoil." Journal of International Economics, forthcoming.

Burstein, A., C. Kurz, and L. Tesar. 2008. "Trade, Production Sharing, and the International Transmission of Business Cycles." Journal of Monetary Economics 55 : 775-795.

Chor, D., and K. Manova. 2011. "Off the Cliff and Back? Credit Conditions and International Trade during the Global Financial Crisis." Journal of International Economics.

De Backer, K. 2011. "Global Value Chains - Managing Risks." OECD DSTI/IND(2011)12.

Dees, S., and Vansteenkiste, I. 2007. "The Transmission of U.S. Cyclical Developments to the Rest of the World." ECB Working Paper No. 798. 
di Giovanni, J., and A. Levchenko. 2010. "Putting the Parts Together: Trade, Vertical Linkages, and Business Cycle Comovement." American Economic Journal: Macroeconomics 2: 95-124.

Eaton, J., S. Kortum, B. Neiman, and J. Romalis. 2011. "Trade and the Global Recession.” NBER Working Paper No. 16666.

Escaith, H., A. Keck, C. Nee, and R. Teh. 2011. “Japan's Earthquake and Tsunami: International Trade and Global Supply Chain Impacts." Voxeu, April 28.

Fabbri, D., and L. Klapper. 2008. "Market Power and the Matching of Trade Credit Terms," World Bank Policy Research Working Paper No. 4754.

Frankel, J., and A. Rose. 1998. "The Endogeneity of the Optimum Currency Area Criteria." Economic Journal 108 : 1009-1025.

Gangnes, B., A. Ma, and A. Van Assche. 2011. "China's Exports in a World of Increasing Oil Prices." Multinational Business Review 19(2): 133-151.

Gangnes, B., and A. Van Assche. 2010. "China and the Future of Asian Technology Trade." In L. Yueh (Ed.), The Future of Asian Trade and Growth: Economic Development with the Emergence of China, London, Routledge, pp. 351-377.

Gangnes, B., and A. Van Assche. 2012. "Global Production Networks in Electronics and Intra-Asian Trade". Chapter 4 in Timo Henckel (ed.), Sustaining Growth and Development in East Asia, Routledge, London.

Grossman, G., and E. Rossi-Hansberg. 2008. "Trading tasks: A simple theory of offshoring." American Economic Review 98(5): 1978-1997.

Hummels, D., I. Ishii, and K.-M. Yi. 2001. "The Nature and Growth of Vertical Specialization in World Trade." Journal of International Economics 54(1): 75-96.

International Monetary Fund. 2010. World Economic Outlook: Recovery, Risk and Rebalancing, IMF, Washington.

Jacks, D., C. Meissner, and D. Novy. 2009. "The Role of Trade Costs in the Great Trade Collapse." VoxEU.org, November 27.

Johnson, R., and G. Noguera. 2012. "Accounting for Intermediates: Production Sharing and Trade in Value Added." Journal of International Economics, forthcoming.

Kiyotaki, N., and J. Moore. 1997. "Credit Chains." Journal of Political Economy 105(2): 211-248.

Ma, A., and Van Assche, A. 2011. "Global Production Networks in the Post-Crisis Era." In M. Haddad and B. Shepherd (Eds.), Managing Openness: Trade and OutwardOriented Growth after the Crisis, World Bank, Washington, D.C., pp. 275-286.

Ma, A., A. Van Assche, and C. Hong. 2009. "Global Production Networks and China's Processing Trade." Journal of Asian Economics 20(6): 640-654.

Miroudot, S., and A. Ragoussis. 2009. "Vertical Trade, Trade Costs and FDI." OECD Trade Policy Working Paper No. 89. 
Mudambi, R. 2008. "Location, Control and Innovation in Knowledge-Intensive Industries." Journal of Economic Geography 8(5): 699-725.

Ng, E. 2010. "Production Fragmentation and Business Cycle Comovements." Journal of International Economics 82(1): 1-14.

Park, S., Lee, J.-W., and Park, C.-Y. 2011. "Emerging Asia: Decoupling or Recoupling?" The World Economy 34(1): 23-53.

Pula, G., and Peltonen, T. 2011a. "Has Emerging Asia Decoupled? An Analysis of Production and Trade Linkages Using the Asian International Input-Output Table." In Y.-W. Cheung, V. Kakkar and G. Ma (Eds.), The Evolving Role of Asia in Global Finance (Frontiers of Economics and Globalization, Volume 9), Emerald Group Publishing Limited, Bingley, pp.255-286.

Pula, G., and Peltonen, T. 2011b. "The Rise of South-South Trade: Does it Mean Less Dependence from the North? Evidence from Emerging Asia." Mimeo.

Raddatz, C. 2010. "Credit Chains and Sectoral Comovement: Does the Use of Trade Credit Amplify Sectoral Shocks?" Review of Economics and Statistics 92(4): 985-1003.

Yi, K.-M. 2003. "Can Vertical Specialization Explain the Growth of World Trade?" Journal of Political Economy 111(1): 52-102. 


\section{Appendix A}

Country coverage:

Our analysis has focused on the following East Asian economies that are most often identified as being part of global value chains:

- Japan

- Asian Dragons : Hong Kong, Taiwan, South Korea, Singapore

- ASEAN-4: Thailand, Philippines, Indonesia, Malaysia

- China and Vietnam

Trade classification:

Relying on the United Nations' Broad Economic Categories (BEC) classification, we use the following table to distinguish between durable and non-durable goods, and to further dissect between intermediate and final goods.

\section{Table A1: United Nation's BEC Code}

\begin{tabular}{|r|l|l|l|}
\hline $\begin{array}{l}\text { BEC } \\
\text { code }\end{array}$ & Description & $\begin{array}{l}\text { Durable/Non } \\
\text {-durable }\end{array}$ & $\begin{array}{l}\text { Intermediate } \\
\text { /Final }\end{array}$ \\
\hline 1 & Food and beverages & $\begin{array}{l}\text { Non-durable } \\
\text { Non-durable } \\
\text { Non-durable }\end{array}$ & \\
2 & Industrial supplies not elsewhere specified & \\
3 & Fuels and lubricants & Durable & Final \\
41 & Capital goods (except transport equipment) & Durable & Intermediate \\
42 & Parts and accessories of capital goods & Durable & Final \\
& (except transport equipment) & Durable & Final \\
51 & Passenger motor cars & Durable & Intermediate \\
52 & Transport equipment & Durable & Final \\
53 & Parts and accessories of transport equipment & Non-durable & \\
61 & Consumer Durables & Non-durable & \\
\hline 62 & Consumer Semi-durable & Non-durable & \\
63 & Consumer Non-durable & \\
7 & Goods not elsewhere specified & & \\
\hline
\end{tabular}


We use the following HS 4-digit codes to identify electronics:

\begin{tabular}{|c|c|}
\hline HS Code & Description \\
\hline 8469 & TYPEWRITERS \& WORD PROCESSING MACHINES \\
\hline 8470 & CALCULATING \& ACCOUNT MACHINES, CASH REGISTERS ETC \\
\hline 8471 & AUTOMATIC DATA PROCESS MACHINES; MAGN READER ETC \\
\hline 8473 & PARTS ETC FOR TYPEWRITERS \& OTHER OFFICE MACHINES \\
\hline 8504 & ELEC TRANS, STATIC CONV \& INDUCT, ADP PWR SUPP, PT \\
\hline 8514 & INDUSTRIAL OR LAB ELEC FURNACES ETC, PARTS \\
\hline 8517 & ELECTRIC APPARATUS FOR LINE TELEPHONY ETC, PARTS \\
\hline 8518 & MICROPHONES; LOUDSPEAKERS; SOUND AMPLIFIER ETC, PT \\
\hline 8519 & TURNTABLES, RECORD \& CASSETTE PLAYERS ETC. \\
\hline 8520 & MAGNETIC TAPE \& OTHER SOUND RECORDERS \\
\hline 8521 & VIDEO RECRDNG/REPRODUC APPAR WHETH/NT VIDEO TUNER \\
\hline 8522 & PARTS AND ACCESSORIES FOR ITEMS 8519 TO 8521 \\
\hline 8523 & PREPARED UNRECORDED MEDIA (NO FILM) FOR SOUND ETC. \\
\hline 8525 & TRANS APPAR FOR RADIOTELE ETC; TV CAMERA \& REC \\
\hline 8526 & RADAR APPARATUS, RADIO NAVIG AID \& REMOTE CONT APP \\
\hline 8527 & RECEPTION APPARATUS FOR RADIOTELEPHONY ETC \\
\hline 8528 & TV RECVRS, INCL VIDEO MONITORS \& PROJECTORS \\
\hline 8529 & PARTS FOR TELEVISION, RADIO AND RADAR APPARATUS \\
\hline 8530 & ELECTRIC SIGNAL, SAFETY OR TRAFFIC CONTROL EQUIP \\
\hline 8531 & ELECTRIC SOUND OR VISUAL SIGNALING APPARATUS, PTS \\
\hline 8532 & ELECTRIC CAPACITORS, FIXED, VAR OR ADJ (PRESET) PT \\
\hline 8533 & ELECTRICAL RESISTORS EXCEPT HEATING RESISTORS, PTS \\
\hline 8534 & PRINTED CIRCUITS \\
\hline 8535 & ELECTRICAL APPARATUS FOR SWITCHING ETC, OV $1000 \mathrm{~V}$ \\
\hline 8536 & ELECTRICAL APPARATUS FOR SWITCHING ETC, NOV $1000 \mathrm{~V}$ \\
\hline 8540 & THERMIONIC, COLD CATHODE OR PHOTOCATHODE TUBES, PT \\
\hline 8541 & SEMICONDUCTOR DEVICES; LIGHT-EMIT DIODES ETC, PTS \\
\hline 8542 & ELECTRONIC INTEGRATED CIRCUITS \& MICROASSEMBL, PTS \\
\hline 8543 & ELECTRICAL MACH ETC, WITH IND FUNCTIONS NESOI, PTS \\
\hline 9006 & PHOTOGRAPHIC STILL CAMERAS, FLASH APPARATUS ETC \\
\hline 9009 & PHOTOCOPY APPARATUS \& THERMOCOPY APPARATUS; PTS \\
\hline 9013 & LIQUID CRYSTAL DEVICES NESOI; LASERS; OPT APPL; PT \\
\hline 9014 & DIRECTION FINDING COMPASSES \& NAVIG INST ETC, PTS \\
\hline 9015 & SURVEY, HYDROGR, METEORO ETC INST; RANGEF ETC, PTS \\
\hline 9018 & MEDICAL, SURGICAL, DENTAL OR VET INST, NO ELEC, PT \\
\hline 9021 & ORTHOPEDIC APPL; ARTIF BODY PTS; HEAR AID; PTS ETC \\
\hline 9022 & X-RAY ETC APPARATUS; TUBES, PANELS, SCREEN ETC, PT \\
\hline 9023 & INST, APPTS\&MODELS,FOR DEMONSTRATIONAL USE\& PARTS \\
\hline
\end{tabular}


9024 $\mid$ MACHINES ETC FOR TESTING MECH PROP OF MATERIAL, PT

9025 HYDROMETERS, THERMOMETERS, PYROMETERS ETC; PTS ETC

9026 INST ETC MEASURE OR CHECK FLOW, LEVEL ETC, PTS ETC

9027

9030 INST ETC FOR PHYSICAL ETC ANAL ETC; MICROTOME; PTS OSCILLOSCOPES, SPECTRUM ANALYZERS ETC, PARTS ETC

9031 MACHINES, NESOI IN CHAPTER 90; PROFILE PROJECT, PT

9032 AUTOMATIC REGULATING OR CONTROL INSTRUMENTS; PARTS

9101 WATCHES, WRIST, POCKET ETC, PREC METAL OR CLD CASE

9102

9103

9105

WATCHES, WRIST, POCKET ETC, CASE NOT PREC NOR CLAD CLOCKS WITH WATCH MOVT, EXCLUDING INST PANEL CLOCK CLOCKS, WITH CLOCK MVTS OTH THAN INST PANEL ETC

9207 MUSICAL INSTRUMENTS WITH SOUND ELECTRIC PROD ETC 


\section{Appendix B}

To determine a country's position in the GVC, we first calculate for each country a set of revealed comparative advantage (RCA) indices:

- Final durable export RCA: $\frac{\text { Share of final durables exports in country i's total exports }}{\text { Share of final durables exports in world total exports }}$

- Int. durable export RCA: $\frac{\text { Share of int. durables exports in country } i^{\prime} \text { s total exports }}{\text { Share of int. durables exports in world total exports }}$

- Final durable import RCA: $\frac{\text { Share of final durables imports in country i's total imports }}{\text { Share of final durables imports in world total imports }}$

- Int. durable export RCA: $\frac{\text { Share of int. durables imports in country i's total imports }}{\text { Share of int.durables imports in world total imports }}$

This leads to table B1:

Table B1: Trade specialization patterns, various East Asian economies, 2007

\begin{tabular}{|c|c|c|c|c|}
\hline & \multicolumn{4}{|c|}{ RCA Indices } \\
\hline & \multicolumn{2}{|c|}{ Intermediate goods } & \multicolumn{2}{|c|}{ Final goods } \\
\hline & Exports & Imports & Exports & Imports \\
\hline United States & 1.13 & 0.85 & 0.87 & 1.15 \\
\hline European Union & 0.90 & 0.90 & 1.10 & 1.10 \\
\hline Japan & 1.15 & 1.02 & 0.85 & 0.98 \\
\hline Hong Kong & 1.05 & 1.26 & 0.95 & 0.74 \\
\hline Singapore & 1.10 & 1.42 & 0.90 & 0.58 \\
\hline Rep. of Korea & 1.10 & 1.14 & 0.90 & 0.86 \\
\hline Taiwan & 1.33 & 1.22 & 0.66 & 0.78 \\
\hline Indonesia & 0.93 & 1.03 & 1.07 & 0.97 \\
\hline Malaysia & 1.16 & 1.48 & 0.84 & 0.52 \\
\hline Philippines & 1.49 & 1.65 & 0.51 & 0.35 \\
\hline Thailand & 0.91 & 1.26 & 1.09 & 0.74 \\
\hline China & 0.70 & 1.21 & 1.30 & 0.79 \\
\hline Vietnam & 0.64 & 0.83 & 1.36 & 1.17 \\
\hline
\end{tabular}

Source: authors' calculations, using CEPII BACI data. 
We can distinguish between four positions in GVCs:

- Final assembly platforms heavily rely on imported inputs to assemble and export final goods. They therefore should have an intermediate import $R C A>1$ and a final export $R C A>1$.

- Component processors heavily rely on imported inputs to process and export intermediate goods. They therefore should have an intermediate import $R C A>1$ and an intermediate export $R C A>1$.

- Component producers intensively export intermediate goods while relying to a limited extent on imported inputs. They therefore should have an intermediate export $R C A>1$ and an intermediate import $R C A$ that is not significantly larger than 1.

- Consumers disproportionately import final goods. They therefore should have a final import $R C A>1$. 
Fig. 1: Average import content share of exports, various industries, 1995 and 2005.

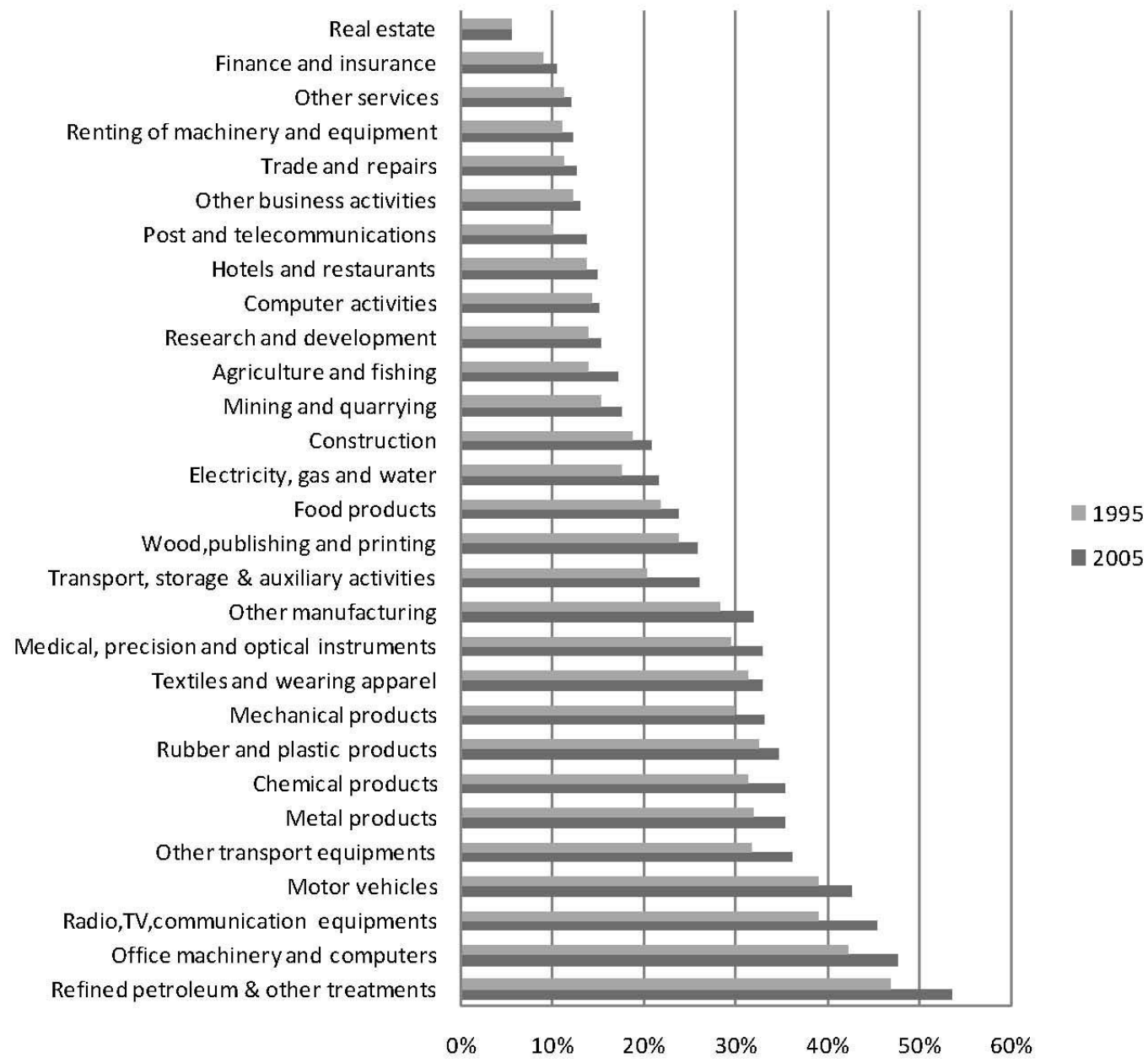

Source: Miroudot and Ragoussis (2009) 
Fig. 2: The share of durable goods and electronics products in total exports, various East Asian economies, 2007

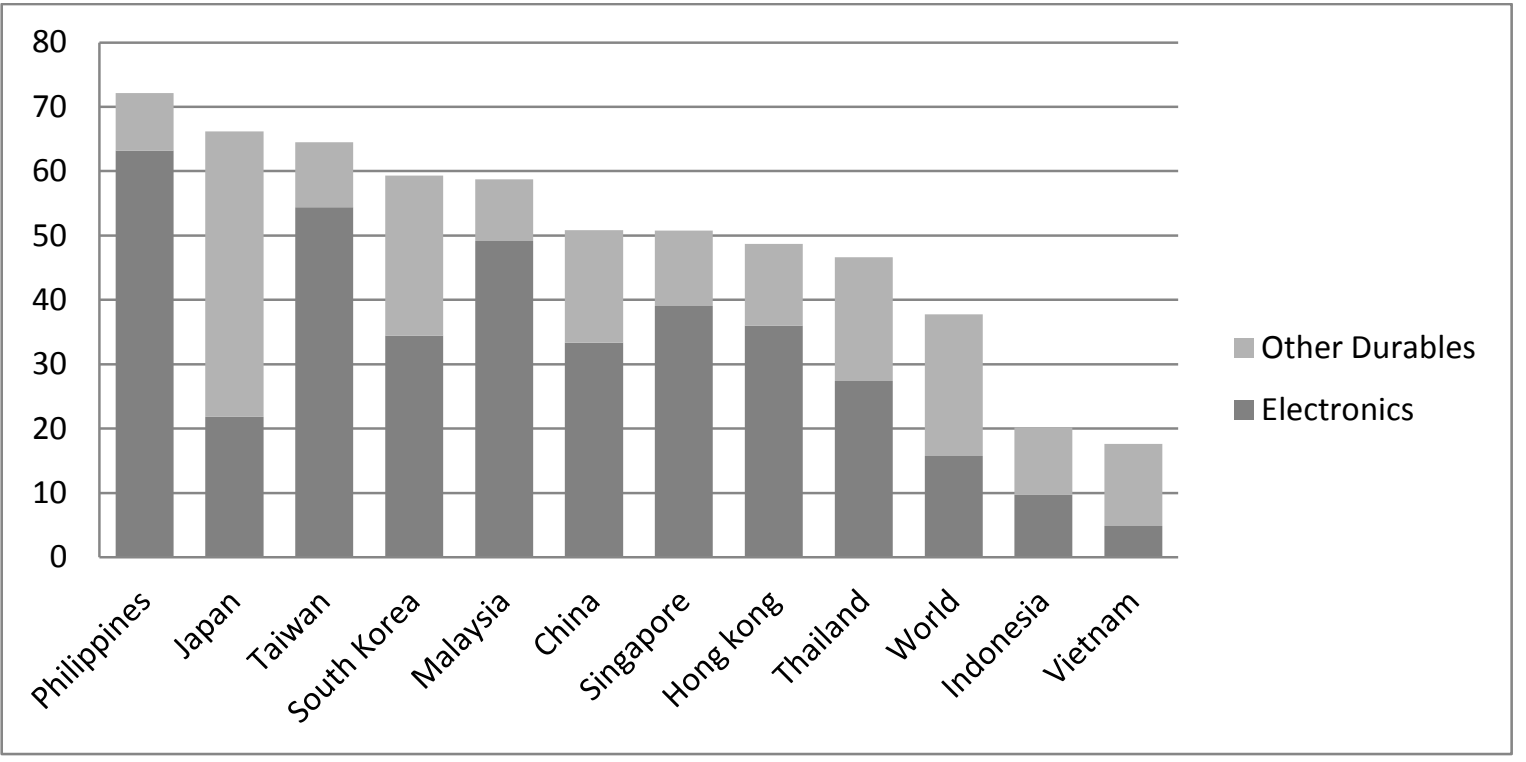

Data Source: authors' calculations, using CEPII BACI data. 
Fig. 3: Source and destination of East Asia's durable goods trade, 2007

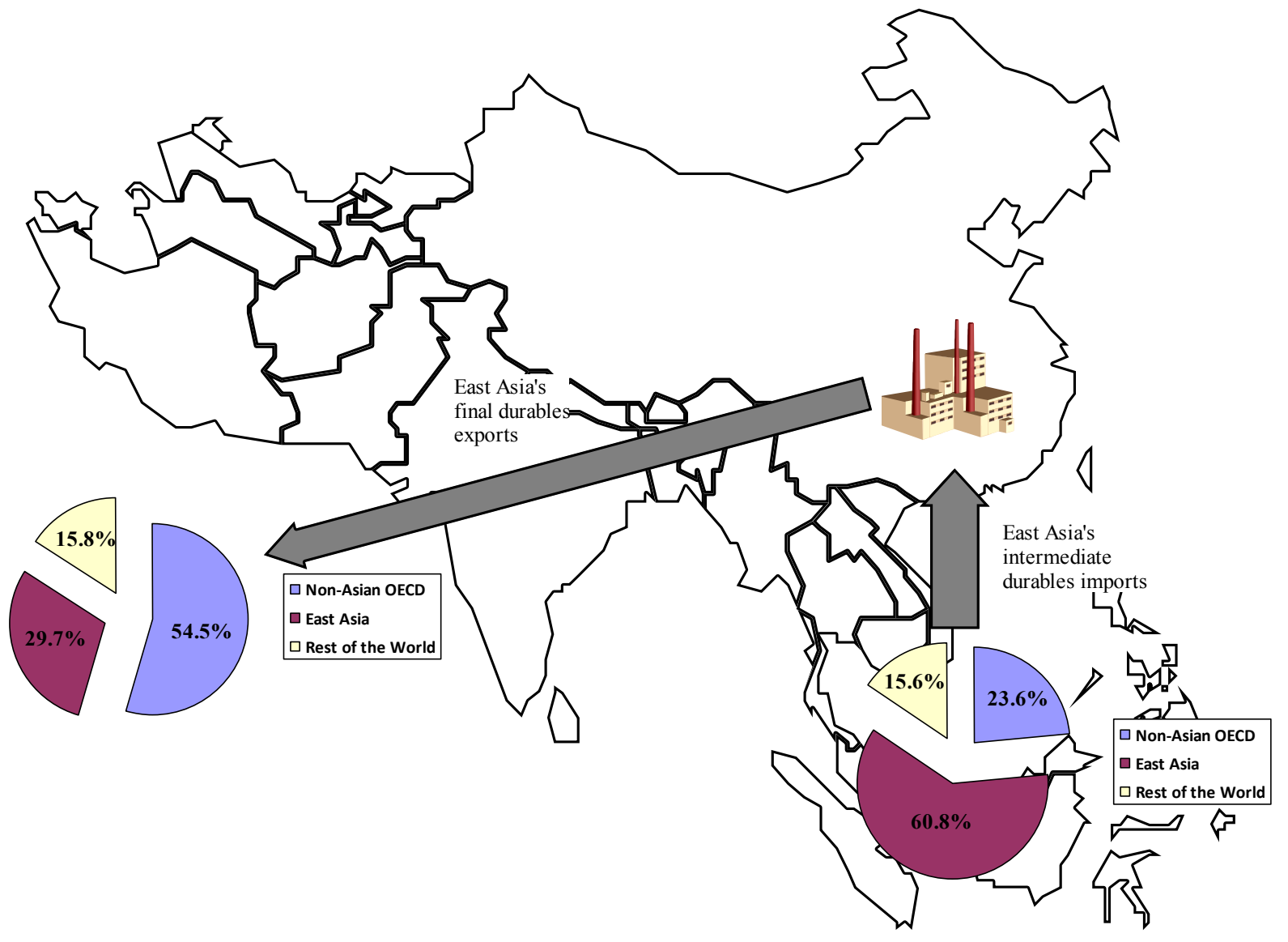

Data Source: CEPII BACI Trade data. 
Fig. 4: Stylized Structure of GVCs in Durable Goods

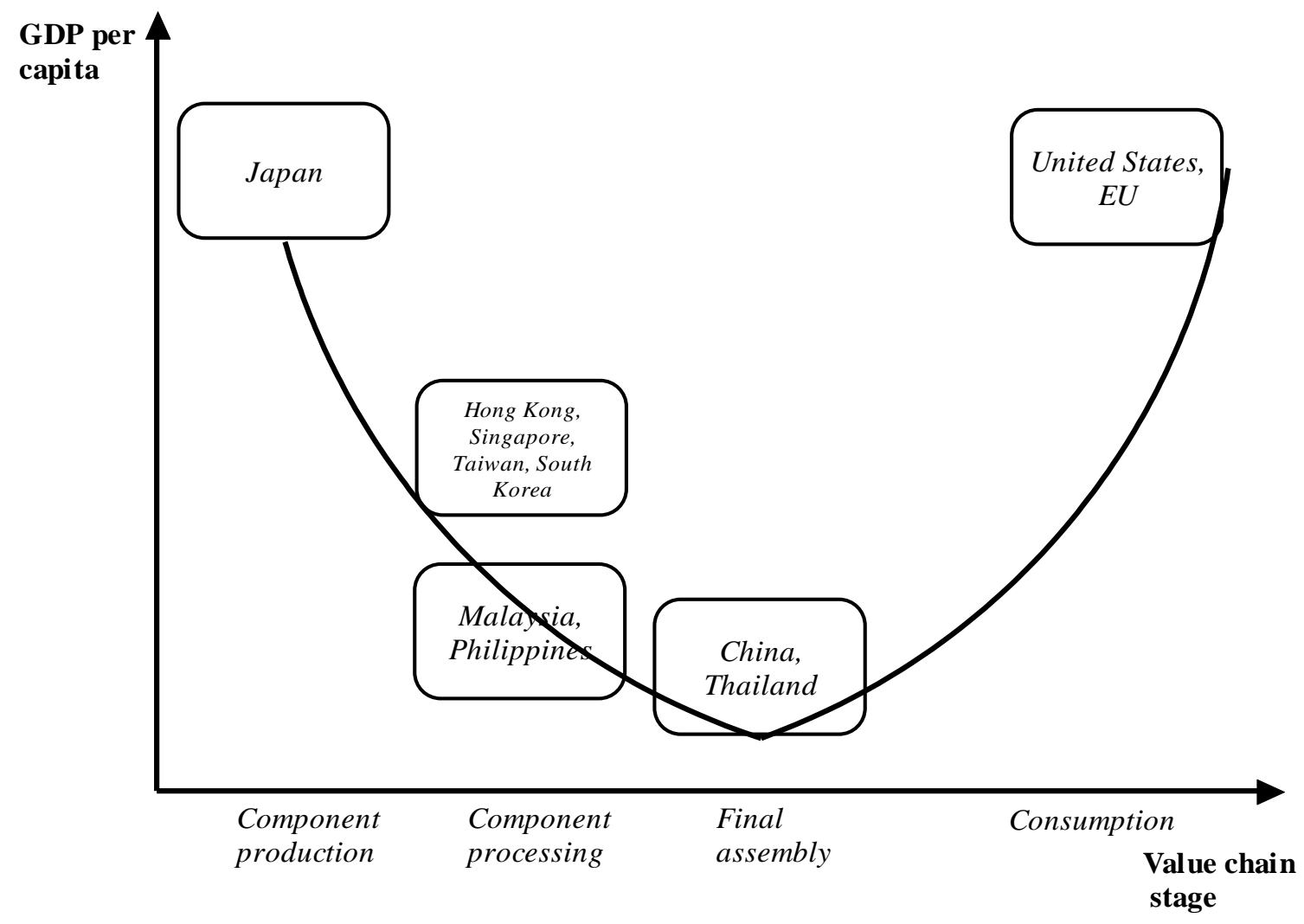

Source: Authors' calculations using CEPII BACI data. 
Fig. 5: A bullwhip effect after a negative demand shock

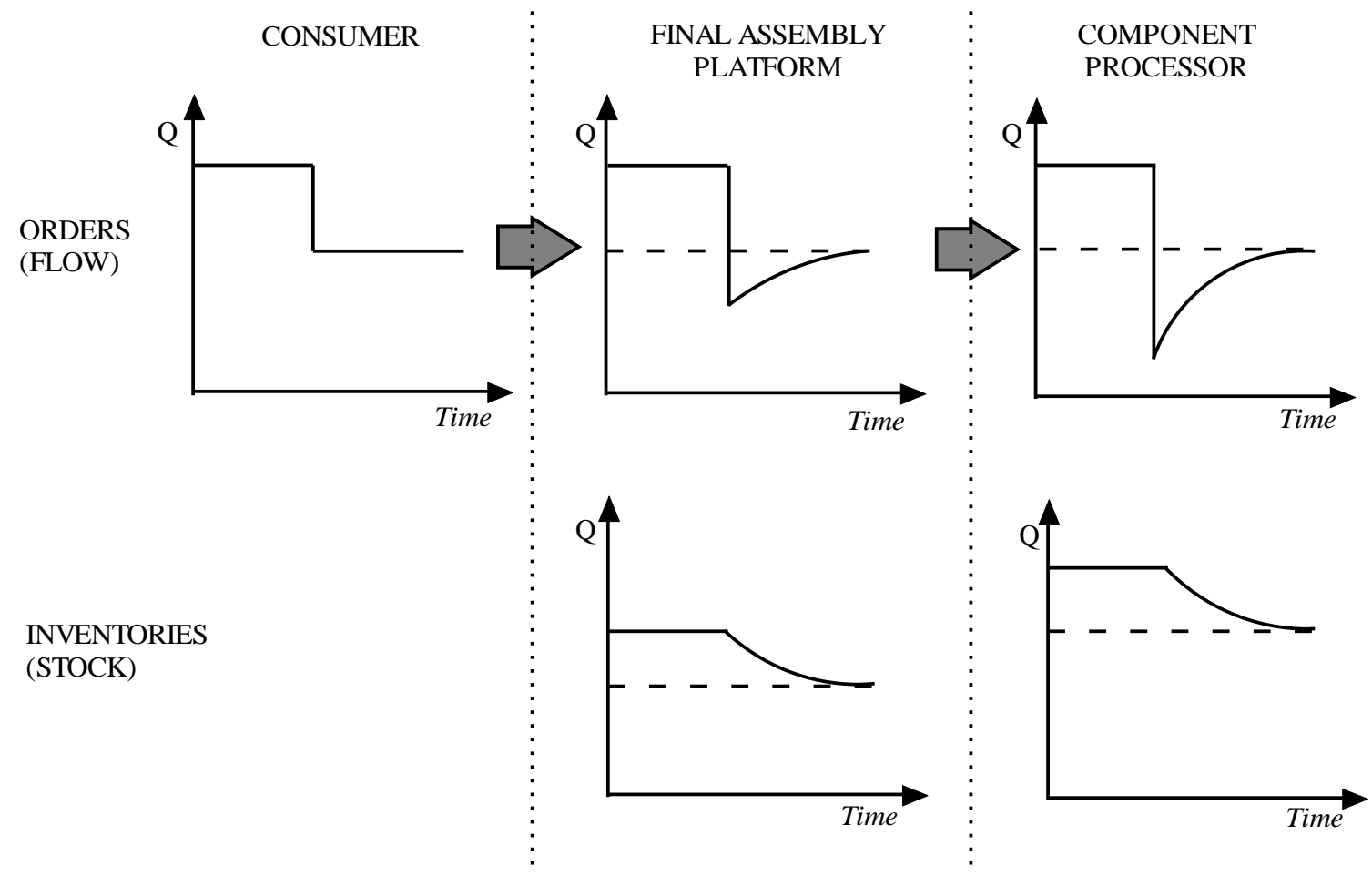

Source: Adapted from Altomonte et al. (2012). 
Fig. 6: Regular versus vertically specialized trade

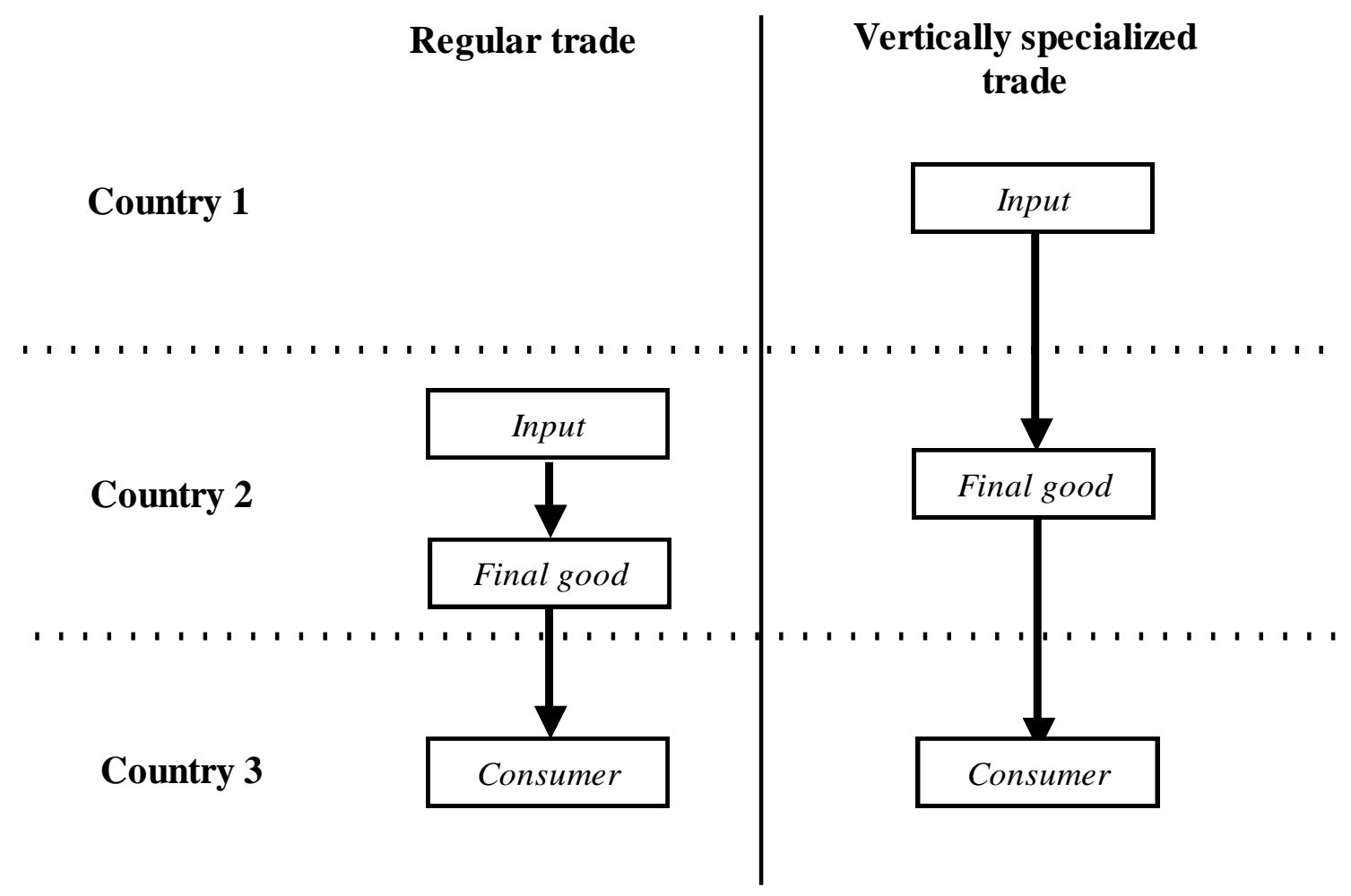

Source: Gangnes et al. (2011). 
Fig. 7: Percent of exports to China that are processing inputs, 2007

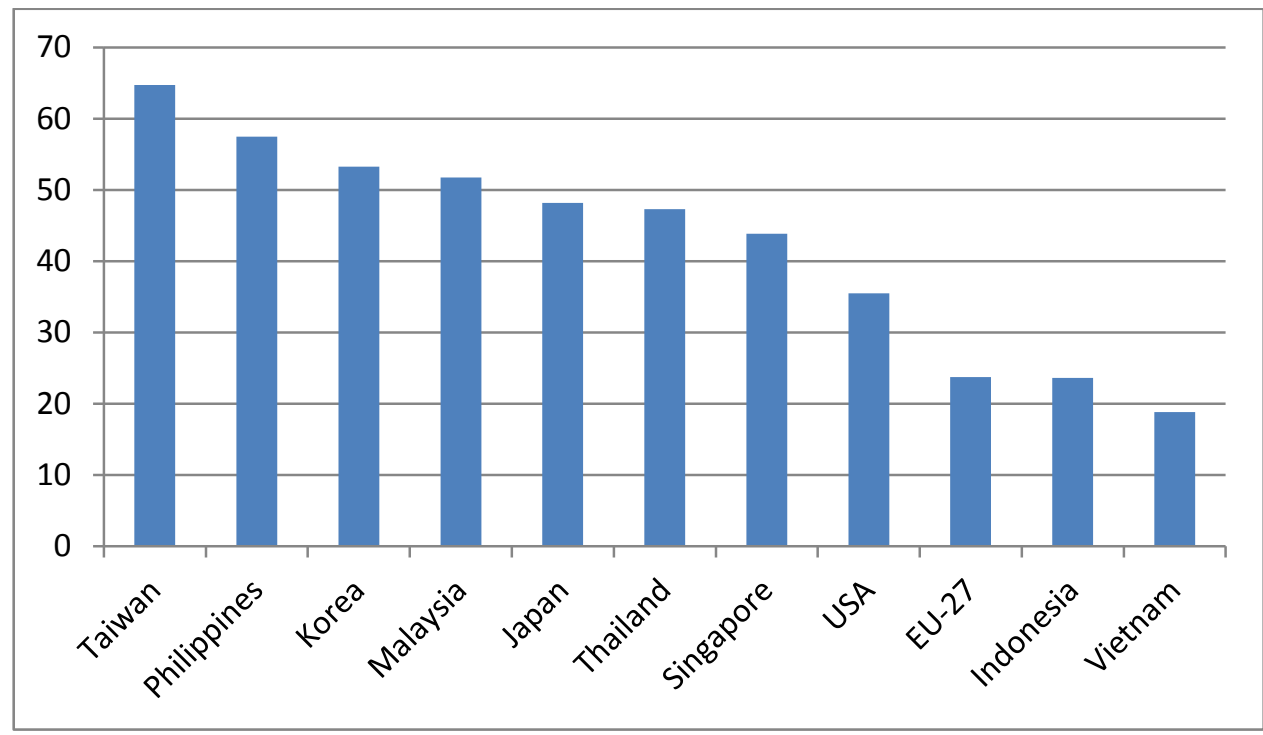

Source: Authors' calculation using China Customs Statistics. The data are adjusted to correct for Hong Kong re-exports. See Ma et al. (2009) for the correction procedure. 
Fig. 8: Direct and Indirect Exports to the U.S. and E.U. as a share of GDP, 2007

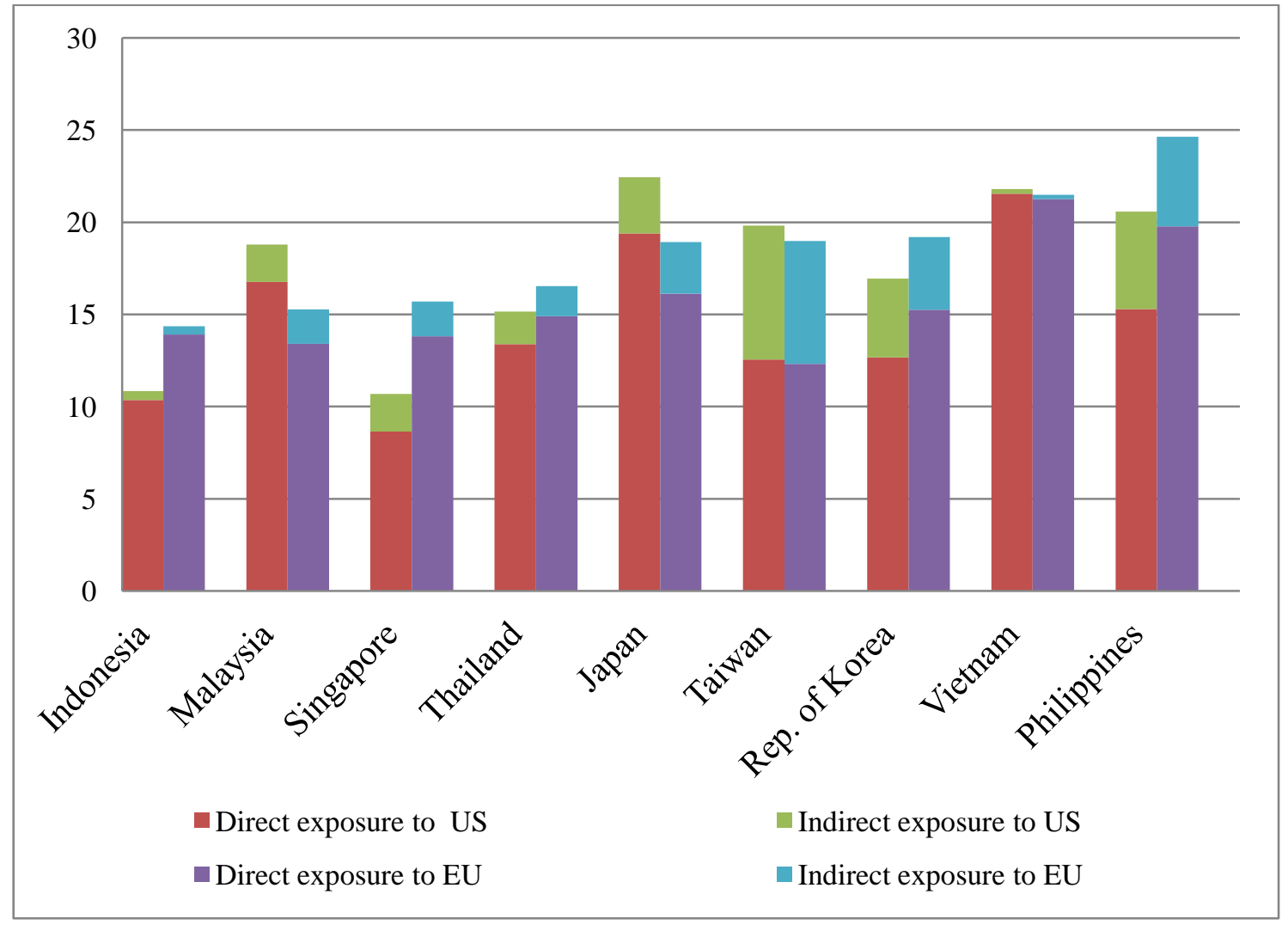

Source: Authors' calculation using China Customs Statistics and CEPI/BACI data. The data are adjusted to correct for Hong Kong re-exports. 
Fig. 9: Share of domestic value added in total exports, 2004

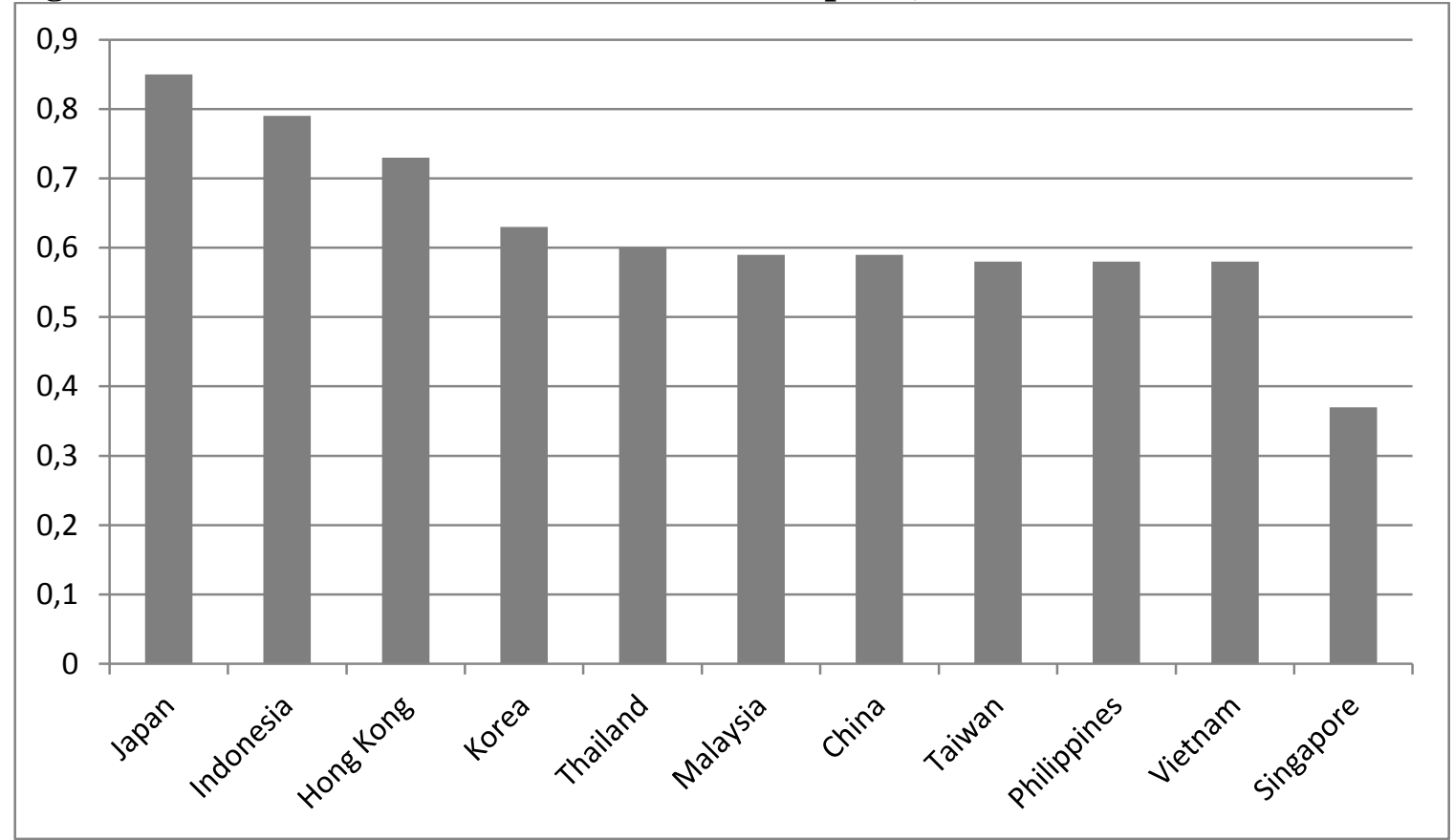

Source: Johnson and Noguera (2012) 
Fig. 10: Ratio of value added exports to gross exports to the U.S., by country, 2004

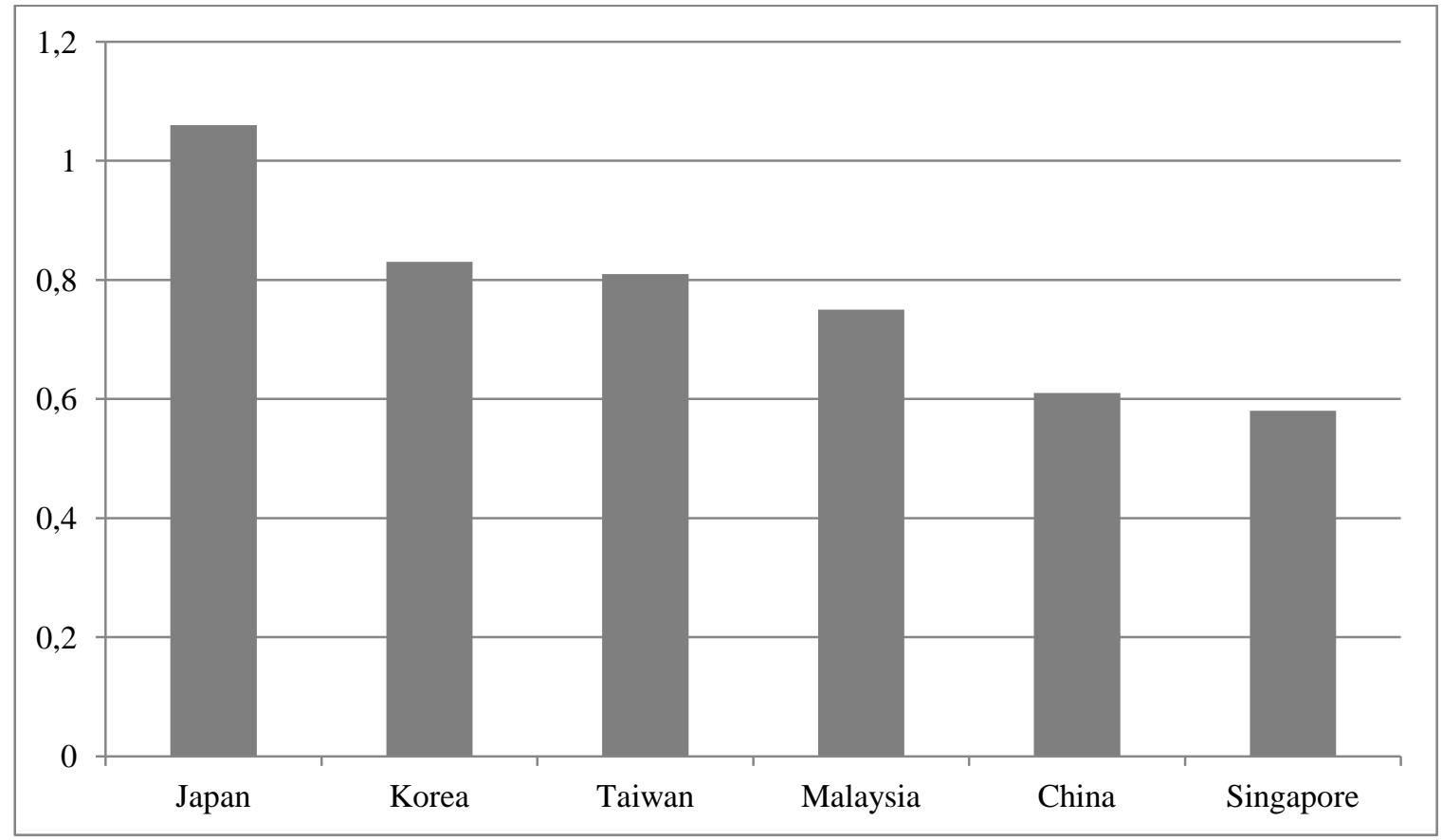

Source: Robinson and Noguera (2012) 
Figure 11: Trade growth compared to the same quarter of the preceding year, 2006Q1-2011Q3

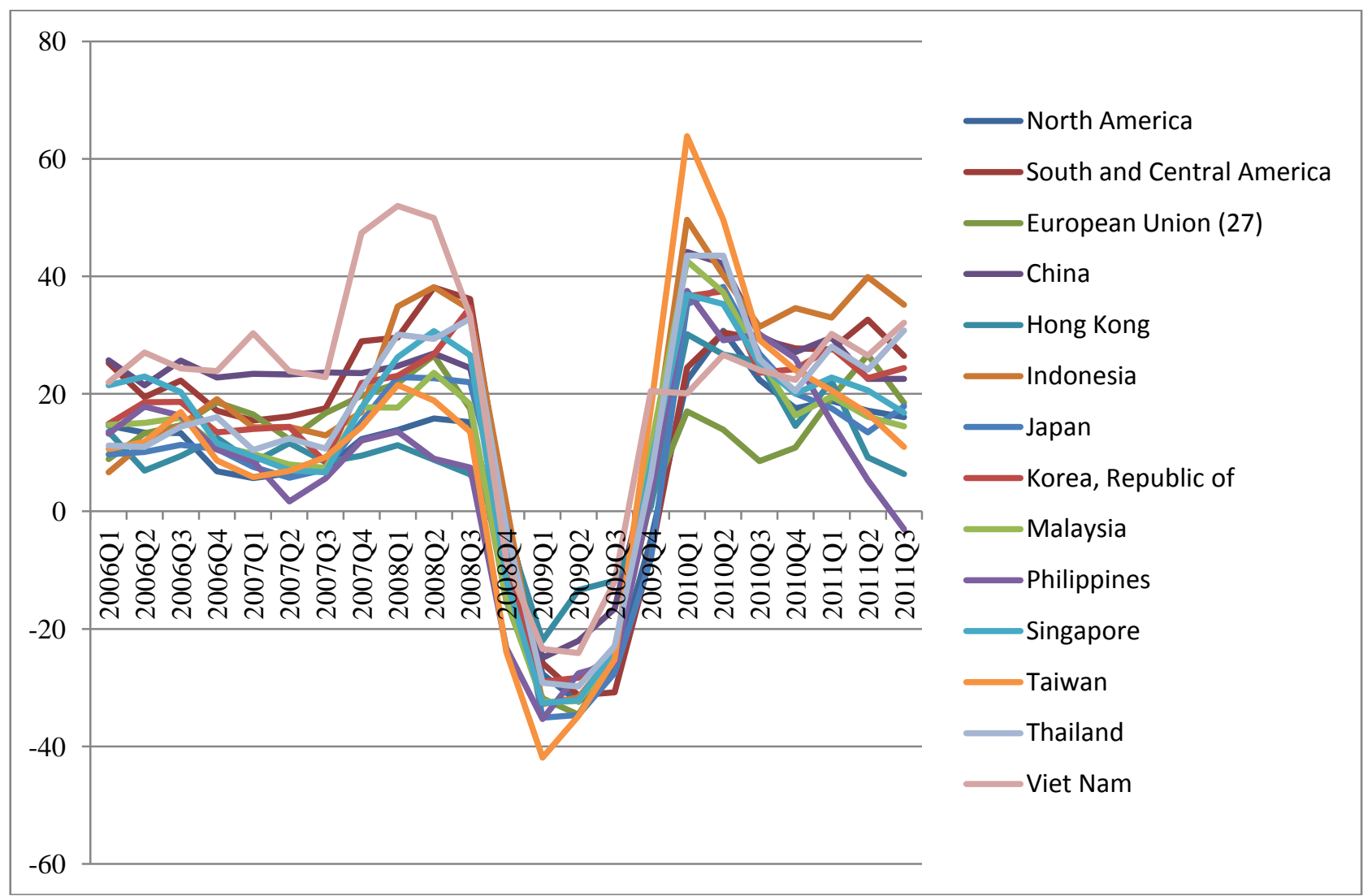

Data source: World Trade Organization 
Fig. 12: Sectoral weights in global final demand and gross trade

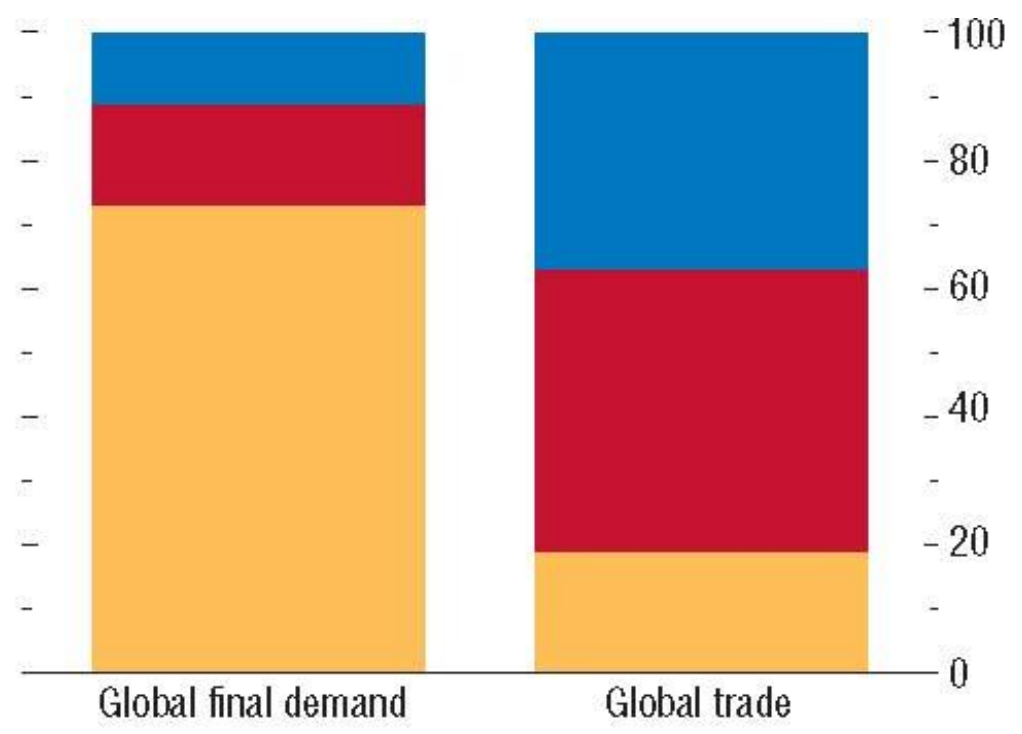

Durables Nondurables Services

Source: Bems et al. (2010). This graph was taken from the IMF's 2010 World Economic Outlook (p. 129). 
Fig. 13: Bullwhip effect in China's Processing trade Regime

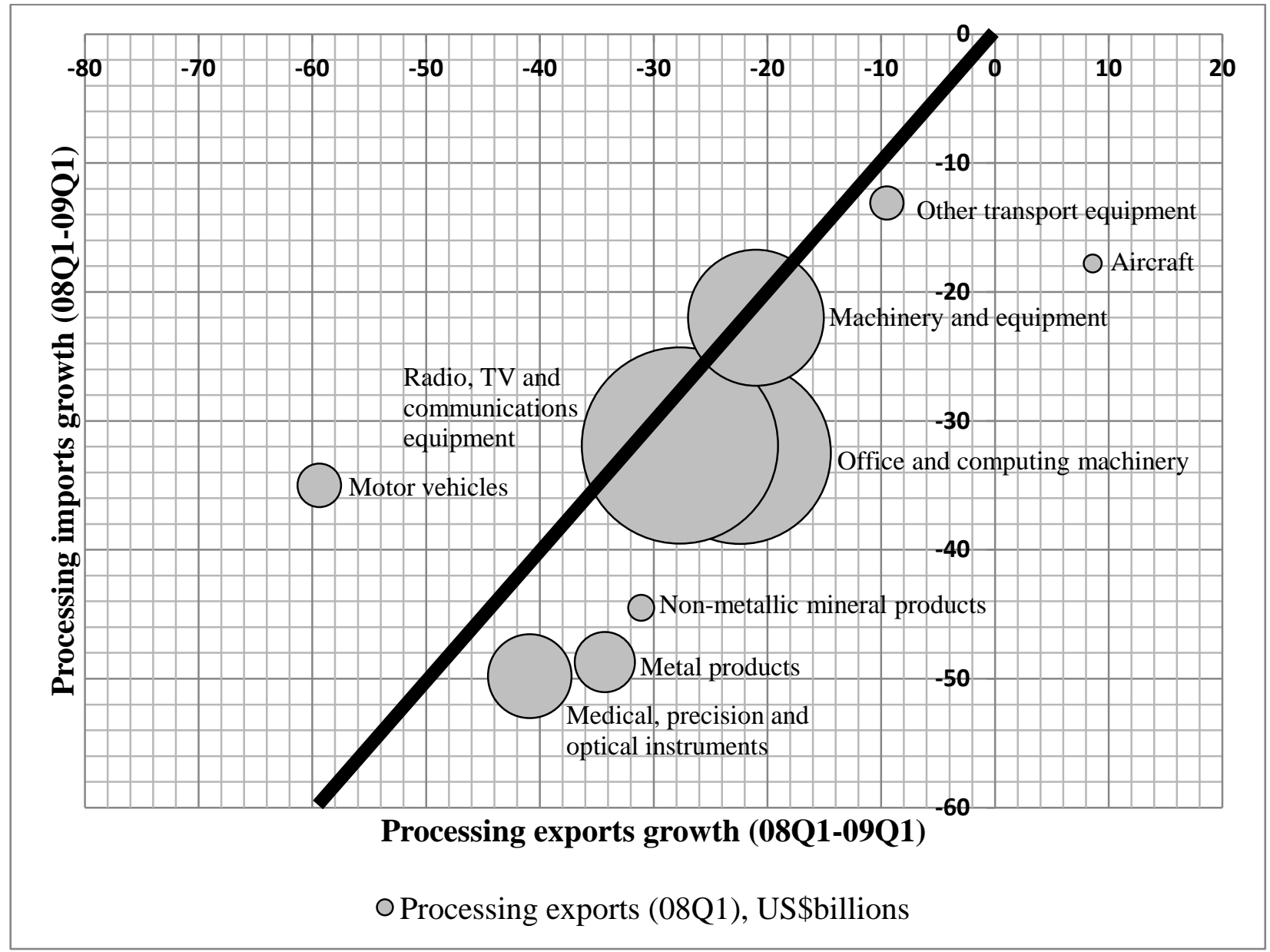

Source: Authors' calculations using China Customs Statistics 